\title{
THE EFFECT OF TUTORING AND CREATIVITY AGAINST STUDENT ACHIEVEMENT OF CLASS XII STUDENTS SMA NEGERI 2 SERANG CITY CIPOCOK JAYA DISTRICT
}

\author{
Asri Yulida \\ Universitas Sultan Ageng Tirtayasa \\ email: asri.yulida@gmail.com
}

\begin{abstract}
This study aimed to determine (1) Effect of tutoring on student achievement, (2) Influence of creativity on student achievement, (3) Effects of tutoring and creativity of student achievement at the same time. The results of the analysis of hypothesis (1) The correlation value of X1 with $\mathrm{Y}$ was 0.6341 with the coefficient of determination was $40.21 \%$, (2) The correlation value of X2 with Y was 0.5981 with the coefficients of determination was $35.77 \%$, (3) The correlation value of $\mathrm{X} 1$ and $\mathrm{X} 2$ with $\mathrm{Y}$ was 0.7188 with the coefficients of determination was $51.66 \%$. Thus, $\mathrm{H}_{0}$ is rejected and $\mathrm{H}_{1}$ is accepted or there was influence of tutoring and creativity on student achievement.
\end{abstract}

Keywords: Tutoring, creativity, and student achievement

\section{INTRODUCTION}

In the world of education, learning is a major activity to gain mastery in science. Mastery in this science can be expressed in the value of student achievement obtained in the final year study results. The high value obtained by the students in the report card is influenced by the quality of the students' learning throughout the year that will have an impact on their ability to take the semester exam and the final exam of the school / UN. In this case, students' creativity to digest knowledge and solve problems quickly and accurately will be helpful.

However, in reality, not all students are hooked on their creativity to be able to find and use quick ways to solve the problem. For example in IPS lessons, when students are required to be able to recall chronologically a historical event, they still remember one by one the important part. In fact, with the development of creativity, they can gather important points of an event in a memorable or imaginary sentence, as Dorothy and Jerome Singer have done research and wrote an imaginative game of the child, they believe that imagination is essential for the development of capabilities intellectual and linguistic. Children remember the ideas and words they have experienced because they can combine ideas with images in their mind (Rahmawati, 2012: 54).

In this case, teachers have a very important role to guide students specifically because the time in the class is not enough to identify the learning difficulties students may have with their own complexity. Especially for some special subjects such as Mathematics, Physics, Chemistry, Biology in science programs and the rest such as Indonesian, English and Civics. Among the solutions provided to overcome these problems is to provide student learning guidance. That way, teachers can diagnose students' learning difficulties and provide the best problem solving. The 
process of learning guidance can also explore and develop the potential and creativity of students to finally improve student achievement. As found in SMA Negeri 2 Serang City that provides learning guidance services to students to overcome learning difficulties that students have and improve creativity and student achievement in learning. But to know how much influence the guidance of learning, there must be data that can state it. Therefore, conducted research with the title "The Influence of Tutoring and Creativity to Student Achievement Class XII SMA Negeri 2 Serang Cipocok Jaya.

\section{Literature Review}

\section{Tutoring}

Guidance has two meanings: general counseling, which has the same meaning as educating or inculcating values, fostering morals, directing students into good people. While the meaning of guidance in particular, that is as an effort or program that is done to help optimize student development. This guidance is provided through the help of problem solving faced, as well as the impetus for the development of the potentials owned by each student (Sukmadinata, 2005: 233). Guidance is the process of helping the individual through his own efforts to discover and develop his ability to gain personal happiness and social benefit (Hamalik, 2010: 7). Guidance can also be interpreted as an effort to provide assistance to learners in order to achieve optimal development (Yusuf and Juntika, 2005: 82).

According to Shah (2011: 68), learning is the process of obtaining meanings and understandings and ways of interpreting the world around students. Learning in this sense is focused on achieving the power of thought and quality action to solve problems that are now and will be faced by students. According to Witherington (Yudhawati and Haryanto, 2012: 32), learning is a change in personality that is manifested as new response patterns in the form of skills, attitudes, habits, knowledge, and abilities. Smaldino (2012: 11) reveals that learning is the development of new knowledge, skills or attitudes when one interacts with information and the environment.

From some understanding above, it is concluded that the guidance of learning can be interpreted as a process of providing assistance from teachers or tutors to students to avoid learning difficulties, which may arise during the learning process, so that students can achieve optimal learning outcomes. Optimal in the context of learning can be interpreted as an effective student, productive and prestative along with gradual changes to become better

This guidance process is very necessary because sometimes students can have difficulty in learning. there are several kinds of learning difficulties as explained by Yudhawati and Haryanto (2011: 143), namely: Learning dissorder or learning disorder, is a state where a person's learning process is disrupted due to the emergence of conflicting responses; Learning disfunction is a symptom in which the learning process undertaken by students is not functioning well, although in fact the student does not indicate any mental subnormality, impairment of sensory devices or other psychological disorders; Under achiever is a student who actually has an intellectual potential that is above normal, but the learning achievement is 
low; Slow learner or slow learning is a slow student in the learning process, so it takes a longer time than a group of other students who have the same intellectual potential level; Learnig disabilities or learning disabilities are symptoms where students are not able to learn or avoid learning, so the learning outcomes are below their intellectual potential. With the emergence of some of these problems, teachers need to do learning guidance with several functions including: Understanding, that is helping students to have an understanding of themselves (potential) and the environment; Prevention, which is an attempt to constantly overcome various problems that may occur and strive to prevent it so as not to be experienced by learners; Development, which is always to create a conducive learning environment, which facilitates student development; Improvement (healing), which is providing assistance to students who have experienced problems. The technique that can be use is counseling, and remedial theaching; Distribution, which helps students to choose extracurricular activities that match their interests, talents, and expertise; Adaptation, which helps educators to adapt educational programs to the educational background, interests, abilities and needs of students; Adjustment, which helps students to adapt dynamically and constructively to educational programs, school rules, or religious norms (Yusuf and Juntika, 2005: 16).

\section{Creativity}

Edward de Bono (1992: 3) reveals a simple notion of creativity: "... bringing into being something that was not there before" which means that creativity is the process of bringing something that did not exist before. Thus, the result of creativity is something new and original, which is a distinctive product of the maker itself and has certain characteristics previously not owned by others.

In simple language, creativity can be interpreted as a mental process that can give birth to new ideas or concepts (Yudhawati and Haryanto, 2012: 168). Furthermore Suryosubroto (2009: 191) explains that creativity is a person's ability to give birth to something new, in the form of ideas and real work, in the form of aptitude and non aptitude, in new works as well as in combination with existing things that are relatively different from what has been there, because creative does not always have meaning only for something that is purely new, but also can to make modifications from existing ones.

Based on the above definition it can be concluded that creativity is an individual mental process that gives rise to effective, effective aesthetic, flexible, integration, succession and differentiation ideas in various fields to solve a problem or to give an update solution of something that has become commonplace.

To be able to help students discover something new, a teacher must be able to create a learning situation established to generate student creativity, should facilitate discussion, question and answer, between students and teachers or students, encourage students to give ideas and opinions in each examples of problems given. As Thorne (2007: 54) reveals that creative Thinking is not just about creative arts, but applies also in the application of the curriculum, helping students to identify alternatives and provide support as they make choices.

According to Oliver (2006: 45) In general, creativity has three commonly found models, namely: Congenital, something attached to a person, usually something intuitive, something to be activated or executed. Capacity for creativity is not described as being the same for everyone; Fostered, something that can be 
developed, perhaps through training or education. Creativity can involve everything, and people can learn whatever they want; A potential, people have some limit to their capacity for creativity, but they can work to achieve this. This is called a process of discovery. The existence of these three models shows the origin of various creativity. Accordingly, Lubart and Guignard (2004: 51) stated that based on studies of creativity development and attention to things that support, creativity is something that can be trained. Thus, creativity not only belongs to the lucky people who have had it since birth, because creativity can also be trained with several stages and processes.

Thorne (2007: 140) reveals a simple idea to accumulate creativity by doing the following steps: ponder for a moment to know exactly what self-inspires, where to go to stimulate creativity, how long we spend time just thinking, what opportunities capable of taking, to participate, or creative activities. Try to visit art galleries, museums, theaters and concerts. Next find someone different to know what we can learn from it. Recall the last time we did creative things, took the opportunity to be creative, explore creative actions and show something different. Then exchange ideas with others, get new information to increase knowledge. Begin to think laterally, use different techniques to help the brain think creatively. Do not keep looking at the past, try to do something new and experiment with different ways. Express our ideas to the closest people by showing different ways of thinking, try to work together and create something new. Do not give up when it fails. Until finally everyone believes that we can do it better later.

All of these explanations confirm that there are many ways to stimulate creativity because each person must have a different dream, so the way to do to make it happen is different. This is where creativity will play an important role to provide the best and easiest solution. Furthermore, because creativity is an ability that exists in the creative person. So to measure a person's creativity can be seen from how creative the person. The first study in Indonesia on creative personality traits was conducted in 1977 by Utami Munandar by comparing the opinions of three groups, namely groups of psychologists, teachers and parents. the results of this study found differences in groups of highly creative people and groups of people who are less creative. In the study, psychologists (Munandar, 2012: 37) suggested 10 personal creative traits, namely: 1) Imaginative; 2) having the initiative; 3) Has broad interest; 4) Independent in thinking; 5) Melit (curious); 6) Nice adventure; 7) Full of energy; 8) Confidence; 9) Willing to take risks; 10) Brave in the establishment and belief. Everyone is possible to have different characteristics.

\section{Learning achievement}

In Indonesian Dictionary (2007: 895), learning achievement is defined as the result achieved (from what has been done, done, and so on). This implies that learning achievement is a result obtained by students in the learning effort it does and this means that learning achievement is a product of a process. This learning achievement is usually expressed in the form of value or achievement index obtained from the results of the measurement of learning achievement that has become an important program officially declared in the results of report cards obtained by students. Measurement of learning achievement can be either test or test. 
Phye (1997: 4) states that academic achievement is acquired knowledge or skills developed in school subjects, usually judged by the tests or grades given by the teacher, or by both. Yet more identical assessments for learning achievement are those expressed in certain values based on previously established provisions for measuring student success in learning. Arifin (2011: 12) reveals that the achievement of learning is the result of the efforts of students who are generally concerned with aspects of knowledge. In other words, the cognitive aspect more dominates the learning achievement.

Thus, learning achievement is the result of student learning after following a certain learning program that is stated by score or value. These results are obtained periodically to determine the development of students or commonly known as mid term semester (UTS) and final exam of the semester (UAS), but, expected in the learning achievement is the improvement made in the material taught.

According to Ahmadi and Supriyono (2004: 138) learning achievement is influenced by several factors, namely: Internal factors that include motivation, ideals, desires, memories, attention, experience, and motives that encourage student learning; External factors that include weather conditions, time (morning, afternoon, afternoon, or night), places, tools used for learning such as stationery, books, props, and the presence of others (family, friends, or teacher) at the time a person is studying.

Learning achievement has several main functions (Arifin, 2012: 15), among others: Learning achievement as an indicator of quality and quantity of knowledge that has been mastered by learners; Achievement learn as a symbol of desire satisfaction curiosity. Psychologists usually refer to this as "a tendency of curiosity and a common human need"; Learning achievement as an information material in educational innovation. The assumption is that learning achievement can be a driving force for students in improving science and technology, and serves as feedback in improving the quality of education; Learning achievement as an internal and external indicators of an educational institution. Internal indicator in the sense that the learning achievement can be an indicator of productivity level of an educational institution. The assumption is that the curriculum used is relevant to the needs of the community and learners. External indicators in the sense that the high level of achievement can be used as an indicator of the success rate of learners in the community. The assumption is that the curriculum used is relevant to the needs of the community; Learning achievement can be used as an indicator of the absorption (intelligence) of learners. In the learning process, learners become the main focus that must be considered, because learners are expected to absorb all the subject matter. High learning achievement can show the ability of students to absorb the subject matter.

\section{METHODS}

The method used in this study is a survey method with the type of research expose facto because in this study was not made treatment on the object of research, but only reveal the facts on self respondents. Surveys are used to collect data or information about large populations using relatively small samples 
(Sukmadinata: 2010: 82). There are three main characteristics of the survey. First, information is gathered from a large group of people to describe certain aspects or characteristics such as: abilities, attitudes, beliefs, knowledge of the population; Secondly, information is collected through the submission of questions (usually termed, orally) from a population; Third, information is obtained from the sample, not from the population. The approach used is a quantitative approach where all the information or research data is manifested in the form of numbers analyzed with statistics and the results described to obtain correlation between the following variables and then calculated the determinant coefficient to determine the level of significance of the influence value of independent variables.

The population in this study is all students of class XII SMA Negeri 2 Serang City IPA program that has followed the guidance of learning since class XI amounted to 320 people, consisting of 8 classes, each class amounted to 40 people. The sampling technique used is simple random sampling technique by taking one class from the population randomly (drawn) on condition that the population should be homogeneous. In this case seen from the educational program they take and the guidance of learning they have lived from class XI.

In this study, the data was collected by using several instruments, namely for the variables of student learning and creativity using a questionnaire whose preparation has been adjusted to the indicators and characteristics of each variable. While for the variable of learning achievement, the data obtained from the average value of student report cards in class XI semester 2. Assessment of student questionnaire results done dengna using Likert scale 1-5. Further data analysis is done with several tests, namely test validity and reliability, normality test, homogeneity test, correlation test and coefficient of determination.

\section{RESULTS}

The result of validity test showed that for learning guidance variable with 24 questions, 21 items are valid and 3 items are not valid with standard error of $1 \%$ or 0.01 ie 0.463 and reliability value of 0.925 , this means instrument has high reliability. As for the creativity variable with the number of questions as many as 30 items, 24 items are valid and 6 items are not valid with the standard error of 5\% or 0.05 of 0.361 and the reliability value of 0.905 , this means the instrument has high reliability. The data normality test was performed using SPSS 18 with the following results.

One-Sample Kolmogorov-Smirnov Test

\begin{tabular}{|c|c|c|c|c|}
\hline & & bimbel & kreativitas & prestasi \\
\hline $\mathrm{N}$ & & 40 & 40 & 40 \\
\hline \multirow[t]{2}{*}{ Normal Parameters ${ }^{\mathrm{a}, \mathrm{b}}$} & Mean & 75.88 & 78.43 & 80.60 \\
\hline & Std. Deviation & 10.034 & 9.142 & 1.411 \\
\hline \multirow[t]{2}{*}{ Most Extreme Differences } & Absolute & .084 & .080 & .190 \\
\hline & Positive & .061 & .080 & .190 \\
\hline
\end{tabular}




\begin{tabular}{|ll|l|l|l|} 
& Negative & -.084 & -.052 & -.115 \\
Kolmogorov-Smirnov Z & .530 & .503 & 1.200 \\
Asymp. Sig. (2-tailed) & .941 & .962 & .112 \\
\hline
\end{tabular}

a. Test distribution is Normal.

b. Calculated from data.

Result of normality test of learning guidance variable obtained by Sig value. $=$ 0.941 . By setting a critical value of 0.05 , then the value of Sig. greater than the critical value, so that the data declared normal distribution. The result of normality test of creativity variable obtained Sig value. $=0.962$. By setting a critical value of 0.05 , then the value of Sig. greater than the critical value, so that the data declared normal distribution. The result of normality test of learning achievement variable got Sig value. $=0.112$. By setting a critical value of 0.05 , then the value of Sig. greater than the critical value, so that the data declared normal distribution.

The calculation of homogeneity test is done by F-Test Two-Sample for Variances technique using microsoft excel 2007 with the following provision: If the value of $\mathrm{f}$ arithmetic <(smaller) than the critical $\mathrm{f}$ value, then the data is declared homogeneous. The following is the acquisition of homogeneity test data.

Variabel Y with X1

\begin{tabular}{|l|l|l|}
\hline & $Y$ & $X 1$ \\
\hline Mean & 80.6 & 75.875 \\
\hline Variance & 1.989744 & 100.6763 \\
\hline Observations & 40 & 40 \\
\hline df & 39 & 39 \\
\hline F & 0.019764 & \\
\hline P(F $<=$ f) one-tail & 0 & \\
\hline F Critical one-tail & 0.586694 & \\
\hline
\end{tabular}

From the table above can be seen that the value of $f$ arithmetic (0.019764) is smaller than the critical $f$ value $(0.586694)$. thus, can be stated that the data is homogeneous.

Variabel $\mathrm{Y}$ with $\mathrm{X} 2$

\begin{tabular}{|l|l|l|}
\hline & $Y$ & $X 2$ \\
\hline Mean & 80.6 & 78.425 \\
\hline Variance & 1.989744 & 83.58397 \\
\hline Observations & 40 & 40 \\
\hline df & 39 & 39 \\
\hline F & 0.023805 & \\
\hline $\mathrm{P}(\mathrm{F}<=\mathrm{f})$ one-tail & 0 & \\
\hline
\end{tabular}


From the table above can be seen that the value of $f$ arithmetic $(0.023805)$ is smaller than the critical $\mathrm{f}$ value $(0.586694)$. thus, it can be stated that the data is homogeneous.

To know the influence of independent variable to dependent variable is done correlation test and coefficient of determination test.

1. Effect of Tutoring Teachers on Student Achievement in Learning

The first hypothesis proposed is:

H0: There is no influence from the learning guidance on student achievement

$\mathrm{H} 1$ : there is influence from the guidance of learning to student achievement

a. Correlation calculation for learning guidance variables with student achievement obtained value 0.6341 , it can be concluded that the guidance of learning with learning achievement has a strong correlation.

b. The calculation of coefficient of determination of learning guidance variables on student achievement obtained value of $40.21 \%$. Thus, it can be dismpulkan that learning guidance gives influence to learning achievement as much as $40.21 \%$, and the rest can be influenced by other factors. Because there has been such influence, then $\mathrm{H} 0$ which states there is no influence from the guidance of learning on student learning achievement is rejected and $\mathrm{H} 1$ which states there is influence of the guidance of learning on student achievement is accepted.

The value has shown great influence. This means learning guidance helps students improve their performance in school. This is in accordance with one of the learning guidance functions disclosed by Yusuf and Juntika (2005: 15) that one of the functions of learning guidance is to help students develop themselves and their potential and prepare students to face exams and improve student learning achievement. Given these results, it can be stated that the function of the guidance has been done well.

2. Effect of Creativity on Student Achievement

The second hypothesis proposed is:

H0: There is no effect of creativity on student achievement

$\mathrm{H} 1$ : there is an influence of creativity on student achievemen

a. Correlation calculation for creativity variable with student achievement obtained value 0,5981 , hence can be concluded that creativity with learning achievement have enough correlation.

b. The calculation of determination coefficient from learning guidance variable to student achievement is $35,77 \%$. Thus, it can be dismpulkan that creativity gives influence to learning achievement as much as $35.77 \%$ and the rest can be influenced by other factors. Because there has been such influence, then $\mathrm{H} 0$ which states there is no influence of creativity on student learning achievement is rejected and $\mathrm{H} 1$ which states there is influence from creativity to student achievement is accepted.

The value has shown great influence. This means that students' creativity is very important to improve their learning achievement, both in terms of receiving the material delivered, understanding the questions given, and the accuracy and speed of students in answering the questions given in both daily and test exams. This is in accordance with the notion of creativity that states that creativity is an individual mental process that gives rise to new ideas, processes, methods or new products 
that are effective, aesthetic, flexible, integration, succession, and efficient differentiation in various fields to solve a problem or to provide an update solution of something that has become commonplace. Given these results, it can be stated that the theory that reveals that creativity is a mental process that can give birth to something new has been proven by the ability of students to do the problem more easily.

3. The Influence of Student Learning Guidance and Creativity Alongside Student Learning Achievement

The third hypothesis proposed is:

H0: There is no effect of counseling learning and creativity simultaneously on student learning achievement

$\mathrm{H} 1$ : there is influence from counseling learning and creativity simultaneously to student's learning achievement

a. Correlation calculation for learning guidance variables with creativity of students obtained value of 0.473 , it can be concluded that the guidance of learning with creativity has enough correlation.

b. The calculation of coefficient of determination from learning guidance variable to creativity of students obtained the final value of $22.37 \%$. Thus, it can be dismpulkan that learning guidance gives influence to creativity as much as $22.37 \%$ and the rest can be influenced by other factors.

c. Correlation calculation for the variables of learning and creativity guidance with student achievement obtained value of 0.7188 , it can be concluded that the guidance of learning and creativity with student achievement has a strong correlation.

d. The calculation of coefficient of determination of the variables of learning and creativity guidance on student achievement obtained a value of $51.66 \%$. Thus, it can be concluded that the guidance of learning and creativity give influence to the learning achievement of $51.66 \%$ and the rest can be influenced by other factors. Because there has been such influence, then $\mathrm{H} 0$ which states there is no influence from the guidance of learning and creativity to student learning achievement is rejected and $\mathrm{H} 1$ which states there is influence from the guidance of learning and creativity to student achievement is accepted.

While for the calculation of significance, it is obtained that $\mathrm{f}$ arithmetic is 19.7715, while from $f$ table obtained the number 19.48. Since $f$ arithmetic is bigger than table, the correlation value of $\mathrm{X} 1$ and $\mathrm{X} 2$ to $\mathrm{Y}$ is significant. The value has shown great influence. This means the guidance of learning and creativity into two supporting elements that should not be separated from efforts to improve student achievement. Both simultaneously give effect to the increasing of student achievement. Tutoring provides students with an easy way to solve problems and provide new, broader insights for students with more time to exchange ideas.

\section{CONCLUSION}

Based on the results of the research that has been done, it can be concluded that the guidance of learning has an important role to explore the potential of students both in terms of learning in classes maupaun in everyday life with a great contribution to the process of learning in the classroom so that students can gain more achievement good. 


\section{Suggestion}

For the teacher as a facilitator should pay more attention to the students. The teacher's learning and evaluation needs to consider how to train student actualization by convergent or divergent thinking. Process evaluation should also provide opportunities for students to develop themselves. Teachers are expected to provide more motivation in accordance with its role as a motivator and attention to the uniqueness of students so that the creativity of students is increasing.

For students are expected to study more actively and dare to reveal all the positive things that exist in him, because everyone must have a great potential that may have been unconscious because of the lack of potential development of self.

For the next researcher who will carry out similar research, to further reinforce the results of research, to be done with a wider population and involves other factors that are suspected to affect student achievement and use more complex methods in order to get more data.

\section{REFERENCES}

Ahmadi, A. \& Supriyono, W. 2004. Psikologi Belajar. Jakarta: Rineka Cipta.

Arifin, Z. 2012. Evaluasi Pembelajaran. Jakarta: Direktorat Jenderal Pendidikan Islam Kementrian Agama.

De Bono, E. 1992. Serious Creativity. New York: Harper Collins.

Depdiknas. 2007. Kamus Besar Bahasa Indonesia. Edisi ke-3. Jakarta: Balai Pustaka

Hamalik, O. 2010. Psikologi Belajar dan Mengajar. Bandung: Sinar Baru Algesindo

Lubart T, Guignard HJ. "The Generality-Specificity of Creativity: A Multivariate Approach" dalam Creativity from Potential to Realization. Edited by Stenberg R, Grigorenko E, singer J. Washington DC: American Psychological Association. 2004. P 51.

Munandar, U. 2012. Pengembangan Kreativitas Anak Berbakat. Jakarta: Rineka Cipta.

Oliver, M. "Students' experiences of creativity" dalam Developing creativity in higher education: an imaginative curriculum. Edited by Jackson . USA: Routledge. 2006. P 44.

Phye, D Gary. 1997. Handbook of Classroom Assesment: Learning, Adjustment and achievement. USA: Academic Press.

Rachmawati Y, Euis K. 2012. Strategi Pengembangan Kreativitas pada Anak. Jakarta: Kencana Predana Media Group 
Smaldino E S, dkk. Teknologi Pembelajaran dan Media untuk Belajar (Instructional Technology and Media for Learning). Diterjemahkan oleh Arif Rahman. Jakarta: Kencana, 2012.

Sukmadinata,N S. 2005. Landasan Psikologi Proses Pendidikan. Bandung: PT Remaja Rosdakarya.

Sukmadinata,N S. 2010. Metode Penelitian Pendidikan. Bandung: PT Remaja Rosdakarya

Suryosubroto, B. 2009. Proses Belajar Mengajar di Sekolah. Jakarta: Rineka Cipta

Syah, M. 2011. Psikologi Belajar. Jakarta: Rajawali Pers.

Thorne, K. 2007. Essential Creativity in The Classroom: Inspiring Kids. USA: Routledge.

Yusuf S., Juntika N. 2008. Landasan Bimbingan dan Konseling. Bandung: Remaja Rosda Karya

Yudhawati R., Haryanto D. 2011. Teori-Teori Dasar Psikologi Pendidikan. Jakarta: Prestasi Pustakaraya. 